\title{
Use of the Reference Service in a Large Academic Library
}

A method for collecting and analyzing records of reference inquiries received by the Reference Department of Yale University Library is described. Variables observed included day, hour, patron affiliation, inquiry type, inquiry mode, time expended, and search points. Inquiries were recorded on forms which also functioned as worksheets for keypunching. An existing computer program generated tables in which observed variables were compared. Tables of search units were also prepared. Conclusions were drawn regarding traffic, staffing, outside use of the library, need for user training programs, and the like. Methods were found to be simple and economical, and information useful in the management of reference service was derived.

$\mathrm{T}$ HIS PAPER SUMMARIZES A STUDY of the use of reference service at Sterling Memorial Library, the central research library of Yale University. The study was conducted during three weeks of April 1970, one week of November 1970, one week of January 1971, and two weeks of April 1971.

The study grew out of the dissatisfaction which the staff of the library's Reference Department felt toward the methods of gathering reference statistics which had been used in the past. Reference questions had simply been recorded by entering marks on a sheet that had been divided into seven parts to represent the days of the week. The

Robert Balay is head, Reference Department, Yale University Library. Christine Andrew is librarian, Bibliographic Center, Research Libraries Group, New Haven, Connecticut. sheets were collected at the end of the week, the numbers tallied, and the results reported in the department's annual report. The count was not taken during the entire year, but only for a two- or three-week period in April, at the end of the annual reporting period.

This practice, or something like it, is commonly used in university libraries. Annual reports of these libraries often contain sections which tabulate the number of reference inquiries for the reporting year and compare this with the performance of prior years.

The method is nevertheless manifestly unsatisfactory, as librarians acknowledge in writing about the measurement of reference service. A tone of pessimism pervades the literature on the subject. Rogers speaks of "the follies we commit and the fallacies we perpetuate" with regard to reference statistics, and Rothstein characterizes the attitude of those who have written about statis- 


\section{0 / College \& Research Libraries • January 1975}

tics of reference service as one of "querulous diffidence."1, 2 A handbook on library statistics, whose aims were to standardize concepts, definitions, and terminology and to make recommendations with regard to the reporting of library statistics, advised flatly that so far as reference service is concerned, "National data are not feasible at this time."3 To some extent, the pessimism is justified. Studies which have analyzed large numbers of inquiries have tended, like Guerrier, to consider only the kinds of questions being asked. ${ }^{4}$ Occasionally, efforts have been made to learn something about users as well as about questions; often, however, the number of inquiries is so small as to cast doubt on the result, ${ }^{5}$ or the information gathered about users is of interest to public libraries but not to others. ${ }^{6}$ Cole's study was carefully planned, but specifically excluded research libraries. ${ }^{7}$ Lacking altogether has been a methodology for gathering detailed information about patterns of reference use-when various categories of users enter the library, what questions they ask, how the questions asked by one category differ from those asked by another, what parts of the library's collections are used in answering various kinds of inquiries, and so on.

One may well ask in light of this whether there is any profit in undertaking yet another statistical study of reference use. It was our view that such a survey may be justified if it provides a means of evaluating the quality of reference service being offered, or if it assists in the management of reference service by providing detailed information about patterns of use. The present study addressed itself primarily to the latter point. We also hoped to develop a methodology which could be adapted for use in other libraries and which could thereby contribute toward the development of standards of reference service. The principal aim, however, was to find out about patterns of reference use in our own library, an aim that we believed would justify the effort expended.

\section{Requirements}

Several factors governed the design of this study.

1. In order to provide a firm basis for generalizations about reference use, a large number of observations would be required.

2. In order to determine total use patterns, all questions would have to be recorded, no matter how trivial they might seem.

3. Since funds were limited, costs would have to be low.

4. Since we would have to use the working reference staff to collect data, procedures would have to be easy to administer and forms simple to complete.

5. Data collecting would have to be done in such a way as to interfere as little as possible with normaI reference work.

6. Data would have to be capable of being analyzed in such a way as to permit comparison of various items in it, so that variables could be seen in relation to one another.

The last point is particularly important. We hoped to discover traffic patterns in reference use, and in addition more detailed information about users and the service provided for them-how the kinds of questions asked by various user categories differed, which categories of questions required the greatest searching time, where librarians looked for answers to inquiries, and so on.

We also hoped that the study would contribute toward answering some of the persistent management problems confronting the Yale Library. Among these were: Is the level of staffing at the reference desks appropriate to the volume of business? Would directories and signs aid users who have simple direc- 
tional inquiries? Should access to the library by users not affiliated with Yale be restricted? Are the various reference collections useful, and are they properly located? Do users have the library skills they need to function in a research library, or would library instruction be of benefit to them?

We recognized that problems like these are complex, and that solutions to them depend on many factors. It seemed evident, however, that knowing about patterns of reference use would help in solving them.

\section{Methods}

The approach that was taken to satisfy the design requirements was to use an interview form which could be filled out during normal treatment of reference inquiries and could double as a keypunching worksheet; to punch data on Hollerith cards, later transferring it to magnetic tape; and to use an existing computer program which would build bivariate frequency tables, permitting various items of data to be seen in relation to one another. (The methodology described here borrows from techniques developed by the Research Department of the Yale University Library, the methods having been used for the analysis of data collected during a study of catalog use conducted from 1967 to 1969. The authors are particularly indebted to Peter Stangl, then of the Yale Medical Library, for his assistance in developing the methodology.)

\section{Collecting Data}

The worksheet is shown in Figure 1. Several months were spent developing and testing preliminary versions before this format was chosen. The only question asked of the user, other than those related to the reference inquiry, was affiliation. The remainder of the form was filled out by the librarian, usually at the conclusion of the inquiry. A form was completed for each person who asked a question at the reference desk each time he or she asked, whether a form had previously been filed or not; a form was filled out for each inquiry, no matter how trivial.

The form was designed to act as a worksheet for keypunching. For this reason, punched card columns are indicated for each field, and the specific coding to be punched in each field is given at the left-hand side of each data item. For example, a librarian recording an inquiry at 3:00 p.m. would check the box under the Time of Day field for 2:00-4:00 p.m.; the keypuncher would punch " 05 " in columns 2-3 of the card representing that inquiry.

Most categories on the worksheet are self-explanatory, but a few words of clarification are necessary. Under Patron Affiliation, a division was made between persons who had official affiliation with the university (coded 01 through 07 ) and those who did not (coded 08 through 11). Cardholders are those persons who are not formally affiliated with the university but have borrowers' cards because they fall within special categories qualifying for this privilege, or because they have purchased cards.

Under Type of Inquiry, a general entry for card catalog inquiries (coded 03) was used for inquiries which did not fit any of the three more specific card catalog entries, or which involved several different kinds of activity at the catalog. Similarly, a general bibliographic entry (coded 07 ) was provided for inquiries which did not fit the more specific bibliographic categories.

The "IPL \& Book ordering" entry (coded 11) was used both for interpretation of entries appearing on the IPL and for assistance in completing book request forms. The IPL (In-Process List) is one product of the Yale University Library's computer-based MachineAided Technical Processing System (MATPS), whose purpose is to aid in the acquisition and processing of li- 


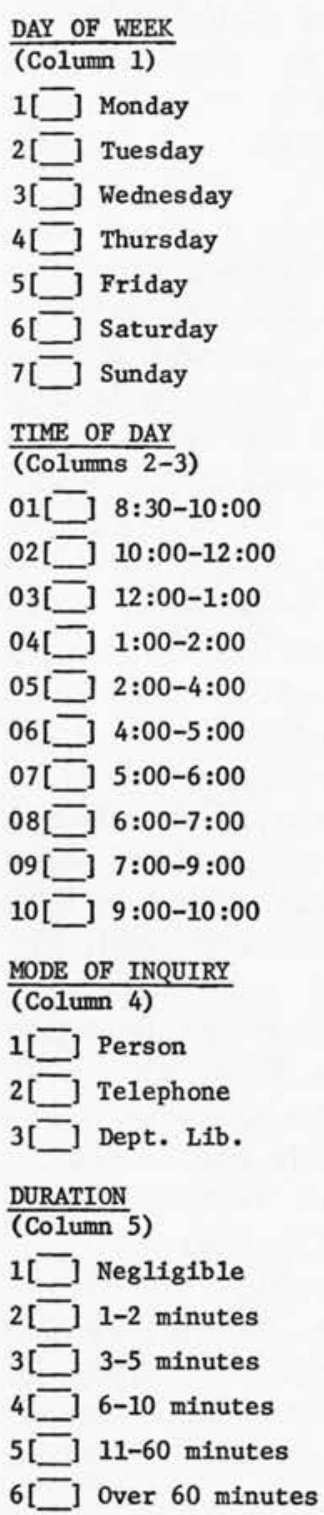

$\frac{\text { PATRON AFFILIATION }}{\text { (Columns 6-7) }}$

01[_] Yale Undergrad

02 [_] Yale Graduate

03[_] Yale Faculty

04[ ] ] Yale Staff

05[-] Yale Library Staff

06[_] Immed. Family of Above

07[_] Yale Alumni

08[_] Undergrad - other Univ.

09[_] Graduate - other Univ.

10[_] Faculty - Other Univ.

11[_] Cardholder

12[]] other

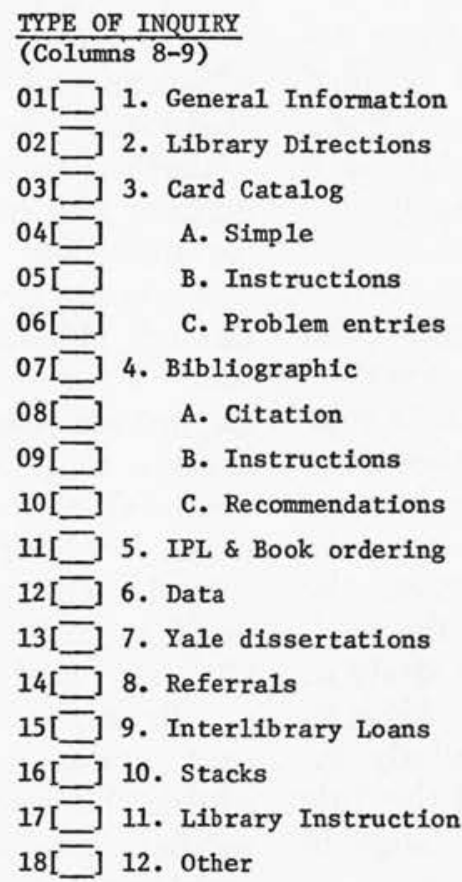

Fig. 1
SEARCH LOCATIONS

(Columns $10-11 ; 12-13 ; 14-15$;

16-17)

01[] No search

02[-] Card Catalog

03[-] Index Collection

04[三] Catalog Reference Area

05[ [] Main Reading Room

06[]] Bibliography Room

07[-] IPL

08[_] Desk Reference Area

09[_] Technical Services

10[_] Reference office

11[三] Stacks

12[-] Other

COMMENTS

\section{Sample Worksheet}

brary materials. The IPL is a main entry list of materials which are on order, or which have been received and are at some point in the processing flow. In its present form, the IPL consists of a cartridge of $16 \mathrm{~mm}$ computer output microfilm containing some 85,000 entries, issued every two weeks; a microfilm reader; and a daily cumulative printout of orders generated since the last edition of the microfilm.

The "Data" entry (coded 12) was used for inquiries as to specific facts, such as addresses, numerical data, statistics, biographical information, quotations, allusions, financial information, dates-all the inquiries that are often called "ready reference." 
The entries under the Search Locations category refer to areas on the ground floor of Sterling Library. Because a large collection of books housed in the Reserve Book Room was being reclassed before being sent to a new intensive use library (called the Cross Campus Library) in the summer of 1970, an entry "Cross Campus Library" was added to the Type of Inquiry and Search Locations categories for November 1970 and continued for the remainder of the study. This entry appears in some of the tables, although it is not on the worksheet.

In each category on the worksheet, librarians were instructed to make only one entry, with the exception of the Search Locations category, where they were instructed to make at least one, but not more than four, entries. It will be seen that in some categories (e.g., Duration and Type of Inquiry) considerable judgment was required on the part of those completing the forms. Librarians were instructed to be as accurate as possible in estimating time spent, and to exercise their best professional judgment in choosing inquiry type.

\section{Interview Method}

Librarians were instructed to conduct themselves at the reference desk in their usual manner as nearly as possible. No special policies or procedures were instituted for test purposes.

The only deviation from normal practice was to ask the user's affiliation. Librarians were instructed to question the user closely at some point during the interview to determine his or her category as a user, and to inform the user if asked that the information was needed in connection with a study of library use which was being conducted. Only a few users wanted more information than that; most had a positive response to the idea of a survey. Librarians then proceeded with normal negotiation of the question, completing the remainder of the form at the conclusion of the inquiry. Completed forms were collected at the end of each day.

\section{Sampling Strategy}

Initially, three weeks in April 1970 were chosen as the period during which the study would be conducted, since this tended to be the busiest period for reference service. April also had been the period usually used to collect reference statistics for annual reporting purposes. It seemed advisable, therefore, to use the same period for this survey in order to compare our findings with those of prior years. Two things became immediately apparent. First, there could be no comparison with prior years, since the data we collected was much more complex than any that had been gathered before, and it was collected much more carefully. Second, a three-week test in spring term might yield some useful information about reference use at that time of year, but it would also be desirable to know whether the patterns were different at other times. Accordingly, four additional test weeks were chosen: one in November 1970, in order to observe patterns during the fall term; one in January 1971, during the reading period for exams; and two in April 1971, in order to see whether there was any variation between the two spring terms. Since one of the aims of the study was to gather data about total reference traffic, it seemed desirable to select several entire weeks in which the total population could be recorded. No other method of selection was employed.

It must be acknowledged that the sample obtained in this manner may not be as representative of the entire population as one might wish. We operated, however, in the environment of a working library, where many other activities were being carried on at the time the study was conducted, and by the same staff. It was essential, therefore, to col- 
lect data at a time when it was possible to do so; tours for new students and lectures on library use take priority early in the fall, for example, to the effective exclusion of other special activities, making November the earliest date in the fall at which we could concentrate on this study. It should also be pointed out that there was remarkably little variation among the weeks chosen for the study, a circumstance that casts doubt on whether more careful sampling would have yielded substantially different results.

\section{Keypunching}

At the conclusion of each statistical period, worksheets were delivered to a keypunch operator. Verbal instructions were given to the operator; since card design was straightforward, and columns and punch codes were given on the worksheets, no difficulties were encountered.

\section{Compilation of Tables}

Data on punched cards were analyzed by using an existing computer program available at the Yale Computer Center. This program compiles various kinds of statistical tables and is described in Yale Computer Center Memorandum No. 38, "Table Program" (Feb. 1968). Sample tables are shown in Figures 2 and 3. It will be seen that the program enables the computer to construct bivariate frequency tables comparing any two variables in the data submitted to it. In the examples shown, Day of Week and Time of Day categories are compared. The table shows that between 2:00 and 4:00 on Wednesday afternoons, 241 users asked some kind of reference question; this was 4.7 percent of the inquiries asked for the duration of the study, 26.6 percent of the inquiries asked on Wednesdays, and 18.1 percent of the inquiries asked between 2:00 and 4:00 p.m.

\section{Costs}

No additional personnel were added to the staff of the Reference Department for purposes of this study; there were thus no direct personnel costs. Direct costs were as follows:

Printing of worksheets

Keypunching

$\$ 50.00$

Computer time fiscal 1970/71 66.00

Computer time, fiscal 1971/72 56.00

Total

$\$ 242.00$

\section{Findings}

The data gathered during this study and the tables prepared by the computer were rather voluminous: 5,096 observations were recorded, from which the computer prepared seventy-eight pages of tables. This by no means exhausted the possibilities for analysis of the data, but the tables which were prepared recorded the data we believed would be most immediately useful. The findings below, and the associated figures, are based on the tables compiled by the computer, and are those which we consider to be of general interest outside the Yale environment.

\section{Variation}

Except as noted below, there was little variation in the data gathered during the four periods of the study.

Traffic was lighter during the week of January 1971 than during any other period of the study. This week fell during a reading period prior to examinations; reference use would appear to decline at such a time. Table 1 gives the number of inquiries for each reporting period.

Use by Yale graduate students rose slightly during the winter months (November 1970 and January 1971) but declined slightly during the spring. Use by persons not affiliated with Yale was higher in the spring than in the winter. Use made of the reference service by outsiders was lower during the period of 
REFERENCE USE STUUDY

FREQUENCY TABLES

\section{ROW YARIABLEE_DAYWK}

VALLS _-_ $0 * \ldots$

$\begin{array}{llllllllllll}0 & 0 & 0 & 0 & 0 & 0 & 0 & 1 & 1 & 0 & 0 & 0\end{array}$

1

2

\begin{tabular}{lllllllllllll}
3 & 4 & 53 & 178 & 90 & 83 & -241 & 77 & 45 & 24 & 73 & 38 & 906 \\
\hline
\end{tabular}

4

5

\begin{tabular}{lllllllllllll}
6 & 0 & 39 & 116 & 48 & 51 & 152 & 67 & 0 & 0 & 0 & 0 & 473 \\
\hline
\end{tabular}

7 . 0

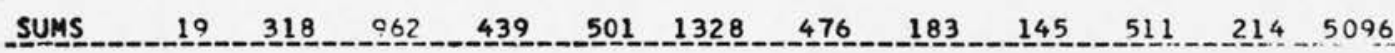

CELL PERCENTAGES BY TOTAL

\section{ROW VAR IABLE DAYWK}

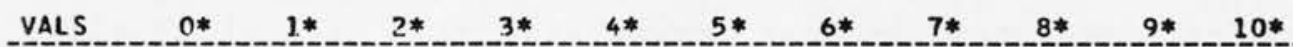

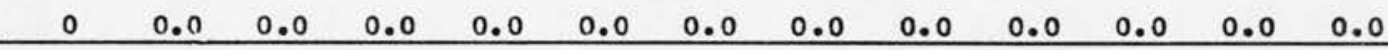

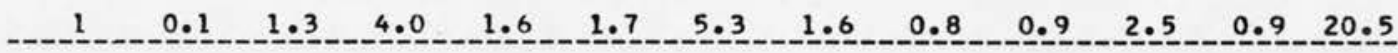

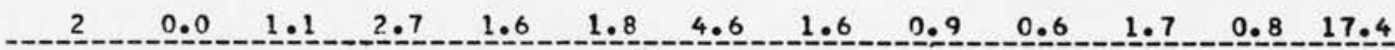

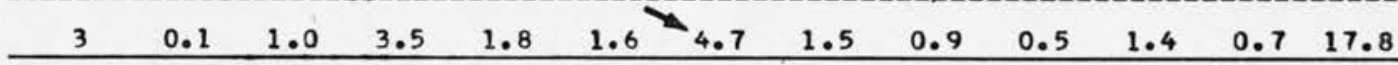

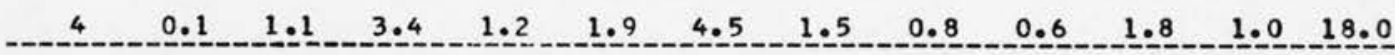
$50.1 \quad 1.0 \quad 3.1 \quad 1.5 \quad 1.9 \quad 3.9 \quad 1.8 \quad 0.2 \quad 0.2$

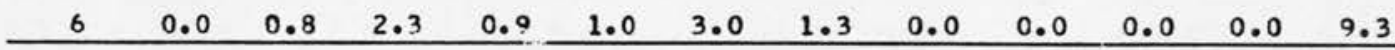

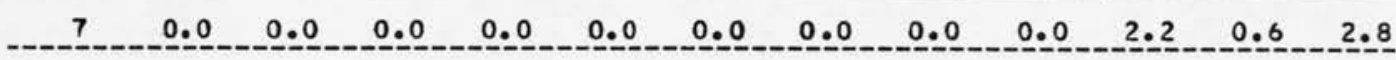
SUMS $0.4 \quad 6.218 .9 \quad 8.6 \quad 9.8 \quad 26.1 \quad 9.3 \quad 3.6 \quad 2.8 \quad 10.0$

Fig. 2

Sample Printout: Frequencies and Percentages by Total 
16 / College \& Research Libraries • January 1975

REFERENCEE USE_STUUDY

CELL PERCENTAGES BY ROW

ROWH_VARIABLEE_DAYHKK COLL_VARIABLLEE_TIMEE

므는

\begin{tabular}{lllllllllllll}
0 & 0.0 & 0.0 & 0.0 & 0.0 & 0.0 & 0.0 & 50.0 & 50.0 & 0.0 & 0.0 & 0.0 & 100.0 \\
\hline
\end{tabular} 1 2

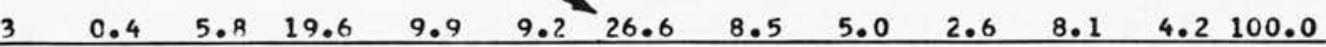

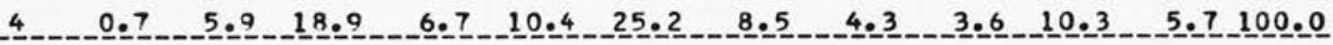
5

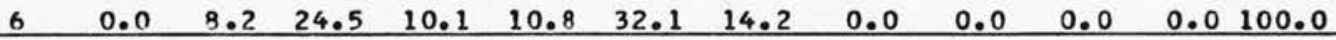

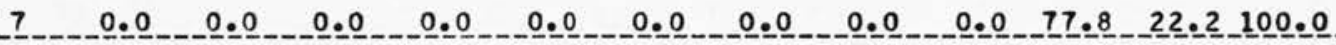

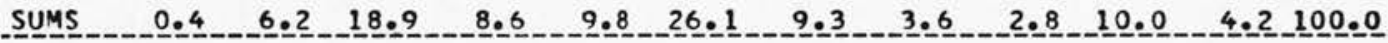

CELL PERCENTAGES BY COLUMN

ROH VARIABLEE_DAYWK _- COLL VARIABLE__IIME

므는

\begin{tabular}{lllllllllllll}
0 & 0.0 & 0.0 & 0.0 & 0.0 & 0.0 & 0.0 & 0.2 & 0.5 & 0.0 & 0.0 & 0.0 & 0.0 \\
\hline
\end{tabular} 1

2

\begin{tabular}{lllllllllllll}
3 & 21.1 & 16.7 & 18.5 & 20.5 & 16.6 & 18.1 & 16.2 & 24.6 & 16.6 & 14.3 & 17.8 & 17.8 \\
\hline
\end{tabular}

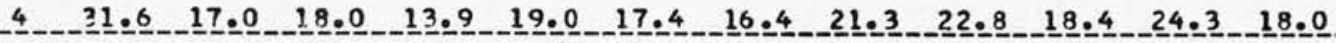
5

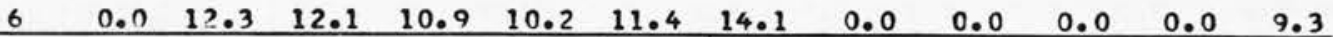

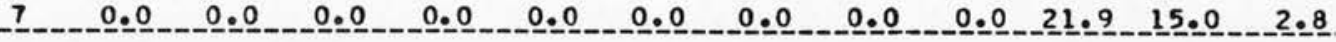

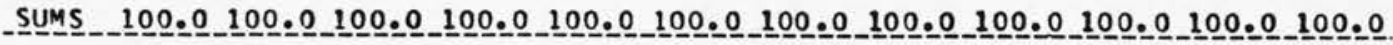

Fig. 3

Sample Printout: Percentages by Row and Column 


\section{TABLE 1}

Number of Inquiries, by Reporting Period

\begin{tabular}{lccc}
\hline \hline Reporting Period & $\begin{array}{c}\text { Number of } \\
\text { Inquiries }\end{array}$ & $\begin{array}{c}\text { Number } \\
\text { of Weeks }\end{array}$ & $\begin{array}{c}\text { Average } \\
\text { Number of } \\
\text { Inquiries } \\
\text { per Week }\end{array}$ \\
\hline April 1970 & 2,252 & 3 & 751 \\
November 1970 & $\mathbf{7 2 8}$ & 1 & 728 \\
January 1971 & 566 & 1 & 566 \\
April 1971 & $\underline{1,550}$ & $\underline{2}$ & $\underline{775}$ \\
$\quad$ Total & 5,096 & $\underline{7}$ & $\mathbf{7 2 8}$ \\
\hline
\end{tabular}

lowest use (January 1971) than during any other time, both in frequency (48 inquiries) and percentage (9.2 percent).

\section{Traffic}

The day of heaviest use was Monday, followed by Thursday, Wednesday, Tuesday, and Friday. Use declined on weekends: Saturday showed only 473 observations, about half the MondayThursday average, and Sunday only 144 observations. This is partly a function of reduced hours on Saturdays and Sundays, but the per-hour figure declined as well. (See Table 2.)

Periods of heavy use occurred at 10:00 a.m. $-12: 00$ noon, at 2:00-4:00 p.m., and at 7:00-9:00 p.m. Troughs occurred at the dinner hour and after 9:00 p.m. More than one-fourth of all inquiries came during the peak afternoon period (2:00-4:00 p.m.); 17 percent came after 6:00 p.m. (See Table

TABLE 2

Number of INQUirIES, BÝ DAY OF WeEK

\begin{tabular}{lrrrr}
\hline \hline Day of Week & $\begin{array}{c}\text { Number of } \\
\text { Inquiries }\end{array}$ & $\begin{array}{c}\text { Percent } \\
\text { of Total }\end{array}$ & Rank & $\begin{array}{c}\text { Average } \\
\text { Number of } \\
\text { Inquiries } \\
\text { per Hour }\end{array}$ \\
\hline Monday & 1,045 & 20.5 & 1 & 11.1 \\
Tuesday & 887 & 17.4 & 4 & 9.4 \\
Wednesday & 906 & 17.8 & 3 & 9.6 \\
Thursday & 916 & 18.0 & 2 & 9.7 \\
Friday & 723 & 14.2 & 5 & 9.7 \\
Saturday & 473 & 9.3 & 6 & 7.9 \\
Sunday & 144 & 2.8 & 7 & 6.9 \\
Not recorded & 2 & - & - & - \\
\cline { 2 - 6 }$\quad$ Total & 5,096 & 100.0 & & \\
\hline
\end{tabular}

TABLE 3

NuMber of INQUIRIES, BY Hour OF DAY

\begin{tabular}{|c|c|c|c|}
\hline Hour of Day & $\begin{array}{l}\text { Number of } \\
\text { Inquiries }\end{array}$ & $\begin{array}{l}\text { Percent } \\
\text { of Total }\end{array}$ & Rank \\
\hline $8: 30-10: 00$ a.m. & 318 & 6.2 & 7 \\
\hline $10: 00$ a.m. $-12: 00$ noon & 962 & 18.9 & 2 \\
\hline $12: 00$ noon- $1: 00$ p.m. & 439 & 8.6 & 6 \\
\hline $1: 00-2: 00$ p.m. & 501 & 9.8 & 4 \\
\hline $2: 00-4: 00$ p.m. & 1,328 & 26.1 & 1 \\
\hline 4:00-5:00 p.m. & 476 & 9.3 & 5 \\
\hline 5:00-6:00 p.m. & 183 & 3.6 & 9 \\
\hline 6:00-7:00 p.m. & 145 & 2.8 & 10 \\
\hline 7:00-9:00 p.m. & 511 & 10.0 & 3 \\
\hline 9:00-10:00 p.m. & 214 & 4.2 & 8 \\
\hline Not recorded & 19 & 0.2 & - \\
\hline Total & 5,096 & 100.0 & \\
\hline
\end{tabular}

3.) On Saturdays, periods of heavy use occurred at 10:00 a.m.-12:00 noon and at 2:00-4:00 p.m., as on weekdays; there was no staffing after 5:00 p.m. Sunday use was heavier than expected; reference service was provided only from 7:00-10:00 p.m., but the number of inquiries compared favorably with the same period for other days of the week.

Most inquiries were delivered in person, about 84 percent; about 15.5 percent came by telephone. Telephone inquiries declined after 5:00 p.m. and on weekends.

\section{Users}

As shown in Table 4, 77.5 percent of the users were affiliated with Yale; 14.3 percent were not. If unrecorded users are excluded, the percentages are: Yale, 84.7 percent; non-Yale, 15.3 percent. The relative importance of outsiders was greater on Saturdays, when they made up 26.8 percent of the user group, than

TABLE 4

YALE Versus Non-Yale Users

\begin{tabular}{lcr}
\hline \hline \multicolumn{1}{c}{ Users } & $\begin{array}{c}\text { Number of } \\
\text { Inquiries }\end{array}$ & $\begin{array}{r}\text { Percent } \\
\text { of Total }\end{array}$ \\
\hline Yale & 3,962 & 77.5 \\
Non-Yale & 715 & $\begin{array}{r}14.3 \\
\text { Not recorded }\end{array}$ \\
$\quad$ Total & $\mathbf{4 1 9}$ & $\mathbf{8 . 2}$ \\
\hline
\end{tabular}


TABLE 5

Yale Versus Non-Yale Users, BY Day of WeEK ${ }^{\circ}$

\begin{tabular}{|c|c|c|c|c|c|}
\hline \multirow[b]{2}{*}{$\begin{array}{l}\text { Day of } \\
\text { Week }\end{array}$} & \multirow[b]{2}{*}{$\begin{array}{l}\text { Number of } \\
\text { Inquiries }\end{array}$} & \multirow{2}{*}{ Yale Percent of } & \multicolumn{2}{|c|}{ Non-Yale } & \multirow[b]{2}{*}{$\begin{array}{l}\text { Daily } \\
\text { Total }\end{array}$} \\
\hline & & & $\begin{array}{l}\text { Number of } \\
\text { Inquiries }\end{array}$ & $\begin{array}{l}\text { Percent of } \\
\text { Daily Total }\end{array}$ & \\
\hline Monday & 825 & 86.5 & 129 & 13.5 & 954 \\
\hline Tuesday & 722 & 87.9 & 99 & 12.1 & 821 \\
\hline Wednesday & 710 & 85.9 & 117 & 14.1 & 827 \\
\hline Thursday & 706 & 85.5 & 120 & 14.5 & 826 \\
\hline Friday & 537 & 81.6 & 121 & 18.4 & 658 \\
\hline Saturday & 331 & 73.2 & 121 & 26.8 & 452 \\
\hline Sunday & 130 & 94.2 & 8 & 5.8 & 138 \\
\hline Total & 3,962 & 84.7 & 715 & 15.3 & 4,677 \\
\hline
\end{tabular}

- Unrecorded users excluded.

during the week. (See Table 5.) On Saturdays, however, the number of inquiries by Yale users declined to less than half its weekday level, while the number of inquiries by outsiders stayed at about its weekday level (121 inquiries versus a weekday average of 117). The larger precentage is, therefore, a function of a smaller population. Use by outsiders declined abruptly on Sundays. During the working day (8:30 a.m. $-5: 00$ p.m.), periods of heavy use by outsiders occurred at 10:00 a.m.-12:00 noon and 2:00-4:00 p.m.; that is, at the same time Yale use was heaviest. (See Table 6.) Use by outsiders declined during the evening. Until 4:00 p.m. outsiders made up about 17 percent of the user population, distributed fairly evenly through- out the day; from that point on, the percentage of outside use declined steadily.

Yale students accounted for more than half of all reference use; 35.5 percent of all users were Yale undergraduates, 24 percent were Yale graduate students. Detailed counts are given in Table 7. Use by Yale undergraduates rose sharply in the evenings. During the working day, Yale undergraduates made up 30.5 percent of the user population; for the 7:00-9:00 p.m. period, the percentage rose to 61.8 , and for 9:00-10:00 p.m., to 63.6. Use by Yale undergraduates rose dramatically on Sundays, to 72.2 percent of the user population, more than twice the normal level.

Use by graduate students was steady throughout the day; they made up

TABLE 6

Yale Versus Non-Yale Users, by Hour of Day ${ }^{\circ}$

\begin{tabular}{lcccrr}
\hline \hline \multicolumn{1}{c}{ Hour of Day } & $\begin{array}{c}\text { Number of } \\
\text { Inquiries }\end{array}$ & $\begin{array}{c}\text { Yale } \\
\text { Daily Total }\end{array}$ & $\begin{array}{c}\text { Number of } \\
\text { Inquiries }\end{array}$ & $\begin{array}{c}\text { Non-Yale } \\
\text { Percent of } \\
\text { Daily Total }\end{array}$ & $\begin{array}{c}\text { Daily } \\
\text { Total }\end{array}$ \\
\hline 8:30-10:00 a.m. & 229 & 81.2 & 53 & 18.8 & 282 \\
10:00 a.m.-12:00 noon & 700 & 82.9 & 144 & 17.1 & 844 \\
12:00 noon-1:00 p.m. & 323 & 80.8 & 77 & 19.2 & 400 \\
1:00-2:00 p.m. & 377 & 82.9 & 78 & 17.1 & 455 \\
2:00-4:00 p.m. & 1,042 & 83.3 & 209 & 16.7 & 1,251 \\
4:00-5:00 p.m. & 374 & 85.6 & 63 & 14.4 & 437 \\
5:00-6:00 p.m. & 152 & 87.4 & 22 & 12.6 & 174 \\
6:00-7:00 p.m. & 113 & 87.6 & 16 & 12.4 & 129 \\
7:00-9:00 p.m. & 450 & 91.8 & 40 & 8.2 & 490 \\
9:00-10:00 p.m. & 195 & 95.1 & 10 & 4.9 & 205 \\
Not recorded & 7 & - & 715 & -15.3 & 10 \\
Total & 3,962 & 84.7 & 715 & 4,677 \\
\hline
\end{tabular}

- Unrecorded users excluded. 
TABLE 7

NUMbER OF INQUiries, BY AFFILIATION OF USER

\begin{tabular}{lrrr}
\hline \hline \multicolumn{1}{c}{ Affiliation of User } & $\begin{array}{c}\text { Number of } \\
\text { Inquiries }\end{array}$ & $\begin{array}{r}\text { Percent } \\
\text { of Total }\end{array}$ & Rank \\
\hline Yale undergraduates & 1,810 & 35.5 & 1 \\
Yale graduate students & 1,223 & 24.0 & 2 \\
$\begin{array}{l}\text { Yale faculty } \\
\text { Yale staff }\end{array}$ & 360 & 7.1 & 4 \\
$\begin{array}{l}\text { Yale Library staff } \\
\text { Immediate family of }\end{array}$ & 151 & 3.0 & 7 \\
$\quad$ Yale users & 521 & 6.3 & 5 \\
$\begin{array}{l}\text { Yale alumni } \\
\text { Undergraduates, other }\end{array}$ & 38 & 1.2 & 12 \\
$\quad$ universities & 138 & 2.7 & 8 \\
$\begin{array}{l}\text { Graduate students, } \\
\text { other universities }\end{array}$ & 116 & 2.3 & 9 \\
$\begin{array}{l}\text { Faculty, other } \\
\text { universities }\end{array}$ & 71 & 1.4 & 11 \\
$\begin{array}{l}\text { Cardholders } \\
\text { Other }\end{array}$ & 92 & 1.8 & 10 \\
Not recorded & 298 & 5.8 & 6 \\
$\quad$ Total & 419 & 8.2 & 3 \\
\cline { 2 - 3 } & 5,096 & 100.0 & \\
\hline
\end{tabular}

- Affiliation of the user was not asked when the inquiry came by telephone.

about one-fourth of the users for any given time period, and the figure never rose above 30 percent or dropped below 20 percent.

Two general conclusions: (1) Officials of the Yale Library have sometimes asserted that outside users pour into the library on evenings and weekends. We found that, so far as reference service is concerned, outside use declines in the evenings and on Sundays, and that periods of heavy or light use by outsiders follow the pattern set by Yale users; Figure 4 illustrates this. (2) The group utilizing the reference service in the evenings and on Sundays was made up predominantly of persons who reside on or near the campus; that is, Yale undergraduates.

\section{Duration}

Only nine inquiries ( 0.2 percent of the total) required more than sixty minutes of searching time. (See Table 8.)

Of all inquiries, 9.8 percent required more than five minutes of searching time. In other studies, the percentage of inquiries requiring more than five min-
TABLE 8

Number of INQUirIEs, By DURATION OF SEARCH

\begin{tabular}{|c|c|c|c|}
\hline Duration of Search & $\begin{array}{l}\text { Number of } \\
\text { Inquiries }\end{array}$ & $\begin{array}{l}\text { Percent } \\
\text { of Total }\end{array}$ & Rank \\
\hline Negligible & 1,289 & 25.3 & 3 \\
\hline $1-2$ minutes & 1,942 & 38.1 & 1 \\
\hline 3-5 minutes & 1,334 & 26.2 & 2 \\
\hline 6-10 minutes & 352 & 6.9 & 4 \\
\hline $11-60$ minutes & 137 & 2.7 & 5 \\
\hline Over 60 minutes & 9 & 0.2 & 7 \\
\hline Not recorded & 34 & $0 . \overline{7}$ & 6 \\
\hline Total & 5,096 & 100.0 & \\
\hline
\end{tabular}

utes of searching time was on the order of 2 to 3 percent. $^{8}$ A number of factors may account for this difference: inaccuracy in recording the time spent; the size of Sterling Library; the fact that the cited study was conducted in undergraduate libraries while ours was conducted in a research library; etc.

Of all inquiries, 25.3 percent could be answered at once ("Negligible" duration).

Questions posed by undergraduates required relatively little searching time; those by graduate students, slightly more; and those by faculty, more searching time than questions from any other group.

\section{Inquiries}

Information-direction questions ("General information" and "Library directions" categories) made up 30.6 percent of inquiries. (See Table 9.)

One inquiry in four related to the card catalog.

Bibliographic inquiries made up 16.4 percent of the total.

In other studies, inquiries for specific facts made up fairly large proportions of the questions asked. ${ }^{9}$ We found that inquiries for data were relatively rare at Sterling Library, only 6.3 percent of the total. Once again, the difference may be in part a function of the difference in population between our study and others. Users who phoned in their in- 


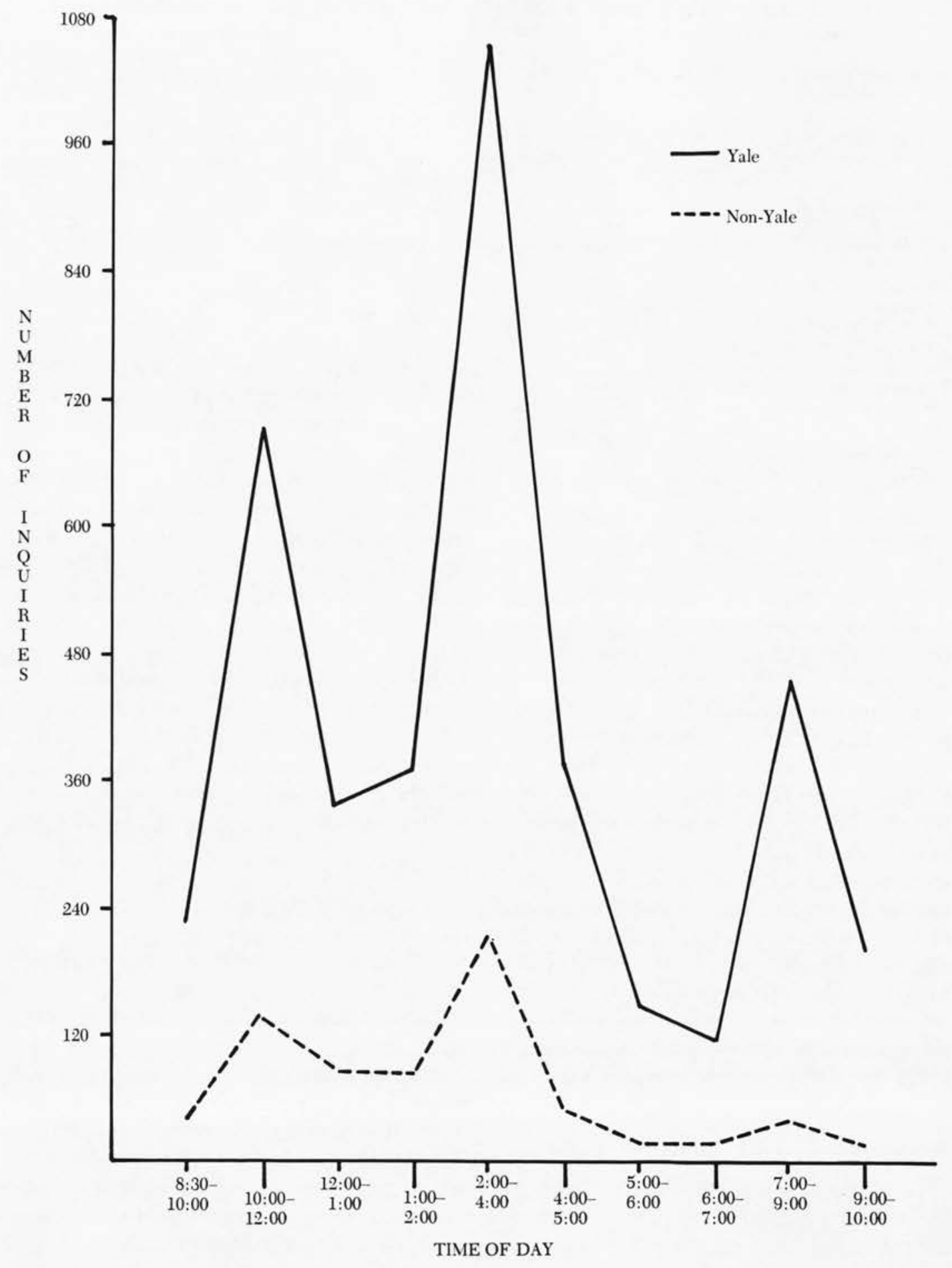

Fig. 4

Yale Versus Non-Yale Users, by Time of Day 
TABLE 9

NUMBER OF INQUIRIES, BY TYPE OF INQUIRY

\begin{tabular}{lrrr}
\hline \hline Type of Inquiry & $\begin{array}{c}\text { Number of } \\
\text { Inquiries }\end{array}$ & $\begin{array}{r}\text { Percent } \\
\text { of Total }\end{array}$ & Rank \\
\hline General information & 571 & 11.2 & 3 \\
Library directions & 987 & 19.4 & 1 \\
Card catalog (General) & 133 & 2.6 & 14 \\
Simple & 817 & 16.0 & 2 \\
Instructions & 190 & 3.7 & 11 \\
$\quad$ Problem entries & 200 & 3.9 & 9 \\
Bibliographic (General) & 140 & 2.7 & 13 \\
Citation & 260 & 5.1 & 6 \\
Instructions & 62 & 1.2 & 16 \\
$\quad$ Recommendations & 377 & 7.4 & 4 \\
IPL \& book ordering & 170 & 3.3 & 12 \\
Data & 322 & 6.3 & 5 \\
Yale dissertations & 115 & 2.3 & 15 \\
Referrals & 220 & 4.3 & 7 \\
Interlibrary loans & 37 & 0.7 & 18 \\
Stacks & 193 & 3.8 & 10 \\
Library instructions & 37 & 0.7 & 18 \\
Cross Campus Library & 54 & 1.1 & 17 \\
Other & 201 & 3.9 & 8 \\
Not recorded & 11 \\
\cline { 2 - 3 } Total & 0.2 & 20 \\
\hline
\end{tabular}

- Category used during November 1970 and April 1971.

quiries made a higher percentage of data inquiries than those who came in person (17.5 percent of telephone inquiries were classed as data inquiries, only 5 percent of inquiries in person).

As one might expect, information-direction questions could be answered quickly, while more substantive card catalog or bibliographic inquiries required more time. Thus 90.2 percent of the "General information" and 89.7 percent of the "Library directions" questions were answered in two minutes or less. By way of contrast, only 32.1 percent of the general bibliographic inquiries could be answered in less than two minutes. It is interesting to note that of questions in the informationdirection categories, 191 (10.7 percent) required three minutes or longer to answer; of these, 19 required six to ten minutes, and 3 required eleven to sixty minutes. These inquiries may have begun as simple directional inquiries and later developed during interrogation into more complex problems, but have been entered, through oversight or otherwise, as directional inquiries. Nevertheless, it cannot be assumed that because an inquiry appears to be a simple information-direction question it always permits a rapid answer, or that the training of a professional librarian will be wasted in pursuing the answer.

We found it interesting to compare the inquiries posed by Yale students and faculty (see Table 10). More than half the questions about stack problems and more than half the requests for recommendation of bibliographic resources were asked by Yale undergraduates, as were two-thirds of the Cross Campus Library questions. Categories of inquiries that Yale undergraduates tended to ask were: general information, library directions, simple catalog lookups, citation problems, bibliographic recommendations, data, and stack problems. This may be taken as a more or less classical undergraduate use pattern: undergraduates are confused by the library and require considerable help in finding their way around in it; they are unfamiliar with card catalogs and require assistance with the simplest lookups; they have difficulty finding materials in the stacks; they know little about bibliographic resources. In other words, they are unfamiliar with the rudimentary mechanics of library use.

Questions asked by Yale graduate students followed the undergraduate pattern closely, except that graduate students asked higher percentages of the inquiries relating to the IPL (In-Process List), to Yale dissertations, and to interlibrary loans. Categories of inquiries that graduate students tended to ask were: general information, library directions, simple catalog lookups, problem entries at the catalog, citation problems, bibliographic recommendations, and IPL and book ordering. Some of the differences between graduate students and undergraduates are not sur- 
TABLE 10

Inquiries by Yale Students and Faculty: Frequency, Row Percentage, and Column Percentage, By Type of INQUiRy

\begin{tabular}{|c|c|c|c|c|c|c|c|c|c|}
\hline \multirow[b]{2}{*}{ Type of Inquiry } & \multicolumn{3}{|c|}{ Yale Undergraduates } & \multicolumn{3}{|c|}{ Yale Graduate Student } & \multicolumn{3}{|c|}{$Y_{\text {gle F F }}$ cul } \\
\hline & $\begin{array}{c}\text { Number } \\
\text { of } \\
\text { Inquiries }\end{array}$ & $\begin{array}{c}\text { Percent } \\
\text { by } \\
\text { Row }\end{array}$ & $\begin{array}{l}\text { Percent } \\
\text { by } \\
\text { Column }\end{array}$ & $\begin{array}{c}\text { Number } \\
\text { of } \\
\text { Inquiries }\end{array}$ & $\begin{array}{c}\text { Percent } \\
\text { by } \\
\text { Row }\end{array}$ & $\begin{array}{l}\text { Percent } \\
\text { by } \\
\text { Column }\end{array}$ & $\begin{array}{l}\text { Number } \\
\text { of } \\
\text { Inquiries }\end{array}$ & $\begin{array}{l}\text { Percent } \\
\text { by } \\
\text { Row }\end{array}$ & $\begin{array}{l}\text { Percent } \\
\text { by } \\
\text { Column }\end{array}$ \\
\hline General information & 201 & 35.2 & 11.1 & 109 & 19.1 & 8.9 & 27 & 4.7 & 7.5 \\
\hline Libra & 433 & & & 236 & 23.9 & 19.3 & 70 & 7.1 & 19.4 \\
\hline Card catalog (General) & 43 & 32.3 & 2.4 & 22 & 16.5 & 1.8 & 11 & 8.3 & 3.1 \\
\hline Simple & 208 & 25.5 & 11.5 & 128 & 15.7 & 10.5 & 63 & 7.7 & 17.5 \\
\hline Instructions & 75 & 39.5 & 4.1 & 50 & 26.3 & 4.1 & 13 & 6.8 & 3.6 \\
\hline Problem entries & 55 & 27.5 & 3.0 & 62 & 31.0 & 5.1 & 24 & 12.0 & 6.7 \\
\hline Bibliographic (General) & 43 & 30.7 & 2.4 & 48 & 34.3 & 3.9 & 6 & 4.3 & 1.7 \\
\hline Citation & 91 & 35.0 & 5.0 & 92 & 35.4 & 7.5 & 10 & 3.8 & 2.8 \\
\hline Instr & 32 & 51 & 1. & 19 & 3 & 1.6 & 4 & 6.5 & 1.1 \\
\hline Recor & 175 & 46. & 9.7 & 110 & 29 & 9. & 20 & 5.3 & 5.6 \\
\hline IPL \& book ordering & 52 & 3 & 2.9 & 69 & 40. & 5. & 31 & 18.2 & 8.6 \\
\hline Data & 9 & & 5 & 5 & & 4. & 23 & 7.1 & 6.4 \\
\hline Yale dissertations & 15 & 13. & 0.8 & 49 & 42.6 & 4.0 & 7 & 6.1 & 1.9 \\
\hline Referra & 61 & & 3 & 35 & & 2 & 12 & 5 & 3.3 \\
\hline Interlibrary loans & 9 & 24.3 & 0.5 & 21 & 56.8 & 1.7 & 1 & 2.7 & 0.3 \\
\hline Stack & 105 & 54 & 5 & 54 & & 4.4 & 15 & 7.8 & 4.2 \\
\hline Libra & 10 & 27 & 0.6 & 10 & 27 & 0.8 & 3 & 8.1 & 0.8 \\
\hline Cross Campus Library & 36 & 66 & 2.8 & 12 & 22.2 & 1.0 & 5 & 9.3 & 1.4 \\
\hline Other & 69 & 34.3 & 3.8 & 45 & 22.4 & 3. & 15 & 7.5 & 4.2 \\
\hline Not recorded & 2 & 18.2 & 0.1 & 3 & 27.3 & 0.2 & 0 & $=$ & x.t \\
\hline Total & 1,810 & 35.5 & 100.0 & 1,224 & 24.0 & 100.0 & 360 & 7.1 & 100.0 \\
\hline
\end{tabular}

prising: graduate students are presumably more aware of the literature of their field, and hence are more likely to inquire about books being processed and to consult the IPL; they are engaged in doctoral research, so they are interested in the dissertation literature.

The differences between the use patterns shown by graduate students and by undergraduates, however, are not nearly so striking as the similarities. One might expect that the greater sophistication and constant exposure to libraries and the scholarly record which are presumed to characterize graduate students might change the way in which they use the library. We found to the contrary that graduate students, like undergraduates, ask many information-direction questions and require elementary help with the catalog and in finding bibliographic resources. The significance of this finding is difficult to assess in the absence of detailed knowledge about the motivations and work patterns of both groups. It seems proper to conclude, however, that the obstacles which cause difficulty for undergraduates (size and complexity of the building and collections, reflected in the size, number, and complexity of the catalogs and other bibliographic aids) still cause problems, and that graduate students have not learned much better than their undergraduate counterparts the rudimentary skills that are needed in using a research library.

Yale faculty asked large proportions of problem catalog entry questions and IPL inquiries. Categories of inquiries that Yale faculty tended to ask were: general information, library directions, simple catalog lookups, problem entries, bibliographic recommendations, IPL and book ordering, and data. This pattern departs from the graduate-undergraduate pattern in the higher incidence of problem entries at the catalog and heavier use of the IPL and book ordering procedures. 
TABLE 11

Number of Searches, by Search Location

\begin{tabular}{lrrr}
\hline \hline \multicolumn{1}{c}{ Search Location } & $\begin{array}{c}\text { Number of } \\
\text { Searches }\end{array}$ & $\begin{array}{c}\text { Percent } \\
\text { of Total }\end{array}$ & Rank \\
\hline No search & 1,992 & 33.3 & 1 \\
Card catalog & 1,564 & 26.1 & 2 \\
Index collection & 346 & 5.8 & 6 \\
Catalog reference area & 435 & 7.3 & 4 \\
Main reading room & 455 & 7.6 & 3 \\
Bibliography room & 166 & 2.8 & 8 \\
IPL & 161 & 2.8 & 9 \\
Reference desk area & 405 & 6.8 & 5 \\
Technical services & 109 & 1.8 & 10 \\
Stacks & 73 & 1.2 & 11 \\
Reference office & 72 & 1.2 & 12 \\
Reserve book room & 2 & 0.0 & 14 \\
Other & 185 & 3.1 & 7 \\
Not recorded & 20 & 0.3 & 13 \\
$\quad$ Total & 5,985 & 100.0 & \\
\hline
\end{tabular}

\section{Search Locations}

Tables of search locations were calculated by merging the data provided by the computer, which tabulated four sets of location tables, one for each location marked on the survey worksheets. (See Table 11.)

For each inquiry, an average of 1.17 search locations was used.

One in three inquiries required no search.

One inquiry in four required use of the card catalog.

The index collection, catalog reference area, main reading room, and the collection of materials at the reference desk each accounted for about 7 percent of the search locations. Bibliography room and IPL each accounted for about 3 percent.

"General information" and "Library directions" queries were generally answered either after no search or from materials kept at the reference desk.

Sixteen percent of card catalog inquiries required the librarian to go to some resource other than the card cata$\log$, most frequently to the catalog reference area or to technical services.

Bibliographic inquiries required consultation of a wide range of resources: card catalog, index collection, catalog reference area, main reading room, and bibliography room were all heavily consulted. If the variety of resources used is a valid gauge, bibliographic queries would appear to be the most complex kind of reference problem.

Other search locations followed directly from the nature of the inquiry. Data inquiries required use of the ready reference collection in the main reading room or the reference desk area; Yale dissertation inquiries required use of the catalog reference area, where tracking tools for Yale dissertations are kept, or the reference office, where card files and correspondence relating to dissertations are kept; etc.

TABLE 12

SEARCh UNITS

\begin{tabular}{|c|c|c|c|c|c|c|c|}
\hline & Monday & Tuesday & Wednesday & Thursday & Friday & Saturday & Sunday \\
\hline $\begin{array}{l}\text { 8:30-10:00 a.m. } \\
\text { 10:00 a.m.-12:00 noon } \\
\text { 12:00 noon-1:00 p.m. } \\
\text { 1:00-2:00 p.m. } \\
\text { 2:00-4:00 p.m. } \\
\text { 4:00-5:00 p.m. } \\
\text { 5:00-6:00 p.m. } \\
\text { 6:00-7:00 p.m. } \\
\text { 7:00-9:00 p.m. } \\
\text { 9:00-10:00 p.m. }\end{array}$ & $\begin{array}{l}11.6 \\
26.4 \\
17.6 \\
22.7 \\
15.1 \\
20.5 \\
15.7 \\
16.2 \\
21.4 \\
21.5 \\
\end{array}$ & $\begin{array}{l}20.4 \\
19.2 \\
30.0 \\
19.7 \\
19.3 \\
14.6 \\
12.1 \\
18.3 \\
22.1 \\
22.2 \\
\end{array}$ & $\begin{array}{r}13.9 \\
31.8 \\
17.0 \\
22.3 \\
19.0 \\
21.9 \\
22.2 \\
5.8 \\
18.7 \\
13.6 \\
\end{array}$ & $\begin{array}{l}30.9 \\
25.3 \\
15.4 \\
32.9 \\
17.0 \\
16.4 \\
25.0 \\
17.4 \\
17.6 \\
20.9 \\
\end{array}$ & $\begin{array}{r}20.0 \\
18.2 \\
14.3 \\
13.8 \\
19.5 \\
18.4 \\
8.0 \\
6.7 \\
7.5 \\
4.3 \\
\end{array}$ & $\begin{array}{r}7.2 \\
15.3 \\
17.6 \\
18.8 \\
19.3 \\
10.5 \\
= \\
= \\
\end{array}$ & $\begin{array}{l}\bar{Z} \\
= \\
\bar{Z} \\
\bar{Z} \\
13.9 \\
\end{array}$ \\
\hline Average & $\overline{18.9}$ & $\overline{19.9}$ & 20.7 & $\overline{21.4}$ & $\overline{16.8}$ & $\overline{14.9}$ & $\overline{18.5}$ \\
\hline
\end{tabular}

Overall hourly average: 19.1 


\section{Search Units}

How much of their assigned desk time do reference librarians actually spend in reference work? In an attempt to answer this question a search units table was compiled (Table 12).

The values for each cell were computed as follows. The number of inquiries for each time period was tabulated. Weights were assigned to each query roughly corresponding to the mean time spent in searching for an answer, as follows:

$\begin{array}{lr}\text { Negligible } & 0.5 \\ 1-2 \text { minutes } & 1.5 \\ 3-5 \text { minutes } & 4.0 \\ 6-10 \text { minutes } & 8.0 \\ \text { 11-60 minutes } & 35.0 \\ \text { Over } 60 \text { minutes } & 60.0\end{array}$

The number of inquiries for each cell was multiplied by the appropriate weight then divided by the number of hours of assigned reference service to obtain the average time expended in searching during each time period.

The search unit figures obtained in this way provided a rough approximation of the amount of time spent in actually negotiating reference inquiries. It should be remembered that searching time is derived from librarians' estimates of the time they spent looking for answers, and that the figures given in the cells of Table 12 do not represent real time, but are artificial numbers arrived at by manipulation of the weighting factors, which are themselves arbitrary. The temptation to think of the cell values as time spent in negotiating inquiries is all but irresistible, however. The following tentative conclusions are offered:

1. The amount of time expended for each hour of assigned desk duty varied from 4.3 (Friday, 9:0010:00 p.m.) to 32.9 (Thursday, 1:00-2:00 p.m.). In only three cells did the search unit figure exceed 30 .
2. The average search unit figure for each hour of assigned desk duty was 19.1. It seems reasonable to conclude that reference librarians spent about twenty minutes of each hour of desk time answering inquiries.

3. Search unit figures were very low for Friday evenings and Saturday mornings. Evening figures (with the exception of Fridays) compared favorably with those during the day, and Sunday figures compared favorably with weekday evening figures.

\section{General Conclusions}

\section{Staffing}

Because of the low number of inquiries and the low search unit figures for Friday evenings and Saturday mornings, we concluded that it was not necessary to provide reference service after 5:00 p.m. on Friday or before 10:00 a.m. on Saturday. As a direct result of this survey, staffing of the reference desks was stopped on Friday evenings in the fall of 1970 .

The principal group served is the Yale student body, undergraduates and graduate students. Use by this group, particularly by undergraduates, increases during the evening. Evening staffing of the reference desks by professional librarians should be continued, except for Fridays.

Both in terms of total inquiries and search unit figures, Sunday evening use compared favorably with weekday evenings. When one considers that the user group on Sunday evenings consisted mostly of Yale students, particularly undergraduates, it is clearly in order to continue Sunday evening staffing.

\section{Directory Information}

The use of directories and signs to provide basic information about the library should assist in handling the high 
level of information-direction questions. A building directory, an improved system of directional signs, and manuals for Sterling and other libraries have been generated, in part as a result of this study and using some of the data it provided. (During the January 1971 portion of the study, librarians were asked to record the exact nature of all information-direction questions. These inquiries were used in making directories and floor plans for Sterling $\mathrm{Li}$ brary.)

\section{Catalog Problems}

The card catalog is the single most important reference aid. Anyone who has used a catalog as large as the one in Sterling Library (about eight million cards) will appreciate that it is an unwieldy and often baffling thing to use. If one considers the number of libraries the catalog is meant to serve, the size of the collections it is meant to describe, and the range of functions it is expected to fill, one cannot fail to be impressed that the catalog performs as well as it does. We believe, however, that the level of problems we encountered in its use is distressingly high (3.9 percent of all inquiries; 14.9 percent of catalog inquiries). The need for a thorough study of the problems readers encounter at the catalog is indicated.

In order to assist readers in using the catalog, the Reference Department, with advice from the Catalog Department, has prepared two manuals, one on general card catalog use, the other a guide for locating serial titles. The experience gained in this survey was useful in the preparation of these manuals.

\section{Bibliographic Inquiries}

Taken together, inquiries which required the consultation of bibliographic sources (i.e., the card catalog, bibliographies and indexes, the IPL, dissertation tracking tools, interlibrary loan verification, library instruction) made up 49.8 percent of all inquiries. Requests for data made up 6.3 percent, and requests for stack assistance another 4.8 percent. All these inquiries call for a measure of bibliographic or technical expertise, or both. It seems to us axiomatic that the presence of a trained professional librarian is essential to handle these inquiries.

There remains a residue of some 40 percent, most of which were information-direction inquiries. It seems likely that paraprofessional assistants could handle these inquiries, and could direct other, presumably more difficult, questions to reference librarians. The decision to use paraprofessional assistants at the reference interview points is not one that may be taken lightly, however. It has been the practice at the Yale Library to staff the reference desks only with professional librarians, on the theory that only professional training provides the background and the commitment that will enable the person behind the desk to interpret successfully the range of reference contacts he or she is likely to receive. Our study was inconclusive on this point. Certainly there was a great number of information-direction questions; but as we noted above, some of them proved on interrogation of the user to be more complicated than they at first appeared. We are not willing to change the present practice of staffing reference desks with professional librarians because of our findings in this study, but we believe that the concept of a separate information desk staffed by paraprofessionals has merit and should be studied more intensively than this study has permitted.

\section{Instruction}

The level of library skills possessed by users, especially undergraduates, is not high. Formal library instruction would be beneficial to students at all 
levels. A program of instruction in bibliographic resources has been begun at the Yale Library.

\section{Outside Use}

The level of use by persons not affiliated with Yale (15.3 percent of all users) approximates that obtained in a recent study of catalog use conducted in Sterling Library. ${ }^{10}$ It was not the intent of our study to treat outside users differently than they are normally treated, or to provide a basis for excluding them or screening their use of the library. Since the questions asked by outsiders tended to be uninvolved and to admit of ready answers, their use of the reference service does not interfere with our ability to serve the Yale user community. It may still prove desirable to screen outsiders on other grounds.

\section{Methods}

The methods used in this study were inexpensive, easy to administer, and interfered minimally with normal reference work. The computer program used is a type that is widely available. The methods could therefore be adapted for use in other institutions.

\section{Utilization}

In addition to providing information for the management decisions discussed above, this study has been useful in ways we did not foresee. When it became necessary because of budget constraints to reduce library hours in the fall of 1971, we were able to provide advice as to when hours might be curtailed with the least effect on our ability to serve readers. Later in the same year, when students challenged the reduction in hours of service and suggested that library funds be saved by eliminating evening reference service, the university librarian was able to use our study to demonstrate that evening use of the reference service was significant, and that the user community during the evening hours was made up predominantly of Yale students; evening reference service was preserved.

\section{REFERENCES}

1. Rutherford D. Rogers, "Measurement and Evaluation," Library Trends 3:177-87 (1954-55).

2. Samuel Rothstein, "The Measurement and Evaluation of Reference Service," Library Trends 12:456-72 (1963-64).

3. American Library Association, Section of Library Organization and Management, Statistics Coordinating Committee, Library Statistics: A Handbook of Concepts, Definitions and Terminology (Chicago: American Library Assn., 1966), p.24.

4. Edith Guerrier, "The Measurement of Reference Service," Library Journal 61:529-31 (July 1936).

5. Herbert Goldhor, "Reference Service Analysis," Illinois Libraries 42:319-22 (1960).

6. The Nelson Associates study of the New York Public Library, for example (User Survey of the New York Public Library Research Libraries [New York: Nelson As- sociates, Inc., 1969]), was intent on learning such things as the age, sex, and occupation of users.

7. Dorothy E. Cole, "Some Characteristics of Reference Work," College \& Research Libraries 7:45-51 (Jan. 1946).

8. See, for example, Billy R. Wilkinson, Reference Services for Undergraduate Students: Four Case Studies (Metuchen, N.J.: Scarecrow, 1972), p.96 passim.

9. Several studies are summarized by Louis Shores in his Basic Reference Sources: An Introduction to Materials and Methods (Chicago: American Library Assn., 1954), p.6-7.

10. Ben-Ami Lipetz, User Requirements in Identifying Desired Works in a Large Library (New Haven, Conn.: Yale University Library, 1970), p.7. (Also available as ERIC document no. ED 042479.) 